\title{
PEMBELAJARAN BERBASIS MASALAH UNTUK MENINGKATKAN PEMAHAMAN KONSEP MATEMATIKA MATERI SEGIEMPAT
}

\author{
Muh. Fitrah \\ Institut Agama Islam Muhammadiyah Bima \\ fitrahoo@yahoo.com
}

\begin{abstract}
ABSTRAK
Pemahaman konsep dalam matematika sesungguhnya langkah awal yang menjadi prioritas guru, sebab salah satu syarat untuk siswa menerima materi-materi selanjutnya. Penelitian ini bertujuan untuk menjelaskan aktivitas guru dan siswa pada pembelajaran berbasis masalah yang dapat meningkatkan pemahaman konsep dan peningkatan pemahaman konsep siswa pada konsep matematika materi segiempat serta respon siswa pada pembelajaran berbasis masalah. Penelitian ini menggunakan penelitian tindakan kelas bersifat kualitatif dan kuantitatif. Subjek penelitian adalah siswa SMP Negeri 1 Dompu Kelas VIIA sebanyak 34 Orang. Instrumen yang digunakan adalah lembar tes, observasi dan wawancara, angket serta dokemen. Data penelitian inipun dianalisis dalam bentuk rata-rata dan persentase kemudian dikombinasikan dengan hasil wawancara yang bersumber dari guru dan siswa. Hasil penelitian menunjukkan pemahaman konsep siswa dapat ditingkatkan menggunakan pembelajaran berbasis masalah, terbukti pada peningkatan setiap siklus pembelajaran. Hal ini didukung pada aktivitas guru dan siswa berdasarkan langkah-langkah pada pembelajaran berbasis masalah yaitu pada siklus pertama aktivitas guru dengan presentasenya 92,5\% meningkat disiklus kedua sebesar 97,5\%, sedangkan aktivitas siswa disiklus pertama dengan presentasenya adalah $93,8 \%$ dan meningkat pada siklus kedua sebesar 97,69\%. Sedangkan pada hasil tes pemahaman konsepnya adalah siklus pertama adalah $79,41 \%$ dengan rata-rata nilainya adalah 77,35 dan siklus kedua pemahaman konsep matematika siswa meningkat secara signifikan, hal ini terbukti presentasenya adalah $88,24 \%$ dengan rata-rata nilainya adalah 84,26 . Sehingga pencapaian antara aktivitas guru dan siswa serta pemahaman konsep matematika siswa pada pembelajaran berbasis masalah mendapatkan respon yang positif berdasarkan transkripsi dari siswa, karena siswa merasa senang dengan suasana belajar yang memaksimalkan aktivitas pada kelompok yang dibagikan.
\end{abstract}

Kata Kunci : Kaidah Matematis, Nirok-Nanggok, Teori Peluang.

\section{PENDAHULUAN}

Pendidikan sangatlah penting untuk modal kehidupan, sebab pendidikan akan membekali siswa secara terencana agar siswa penuh mengembangkan potensi yang ada dalam diri agar memiliki akhlak mulia, kepribadian yang cerdas, kemampuan berpikir secara totalitas, serta keterampilan oleh dirinya, masyarakat, Bangsa, dan Negara (Depdiknas, 2003). Sebab salah satu solusi untuk hal demikian adalah melalui pendidikan matematika, sebab matematika adalah salah satu mata pelajaran yang diwajibkan dipelajari 
oleh siswa. Seperti ungkapan Fitrah (2016) bahwa pembelajaran matematika di sekolah yang akan memfasilitasi siswa agar dapat membangun kemampuan berpikir.

Peneliti pendidikan matematika menyimpulkan bahwa matematika selalu berurusan dengan rumus, bentuk penyelesaian serta struktur yang identik dalam matematika. Sehingga ketika mengembangkan pembelajaran matematika, akan fokus pada keterampilan berhitung (Effendi, 2010). Dalam matematika yang namanya menjelaskan konsep yang beraitan dengan rumus bahkan bentuk dari penyelesaiannya tentu sesungguhnya adalah dibutuhkan pemahaman konsep yang kuat. Diketahui bersama bahwa bagian dari pembelajaran konsep yang dapat dilakukan adalah menggambarkan contoh yang berhubungan dengan konsep yang selanjutnya akan dipelajari dan memberi kesempatan siswa untuk mengidentifikasi sendiri konsep tersebut. Oleh karena itu, makna dari pemahaman itu sendiri senada dengan penjelasan menurut Fitrah (2016) yang menjelaskan suatu kegiatan yang sistematis dalam memahami dan mengemukakan tentang sesuatu yang diperolehnya. Pada pembelajaran matematika berisi sejumlah konsep yang harus diminati siswa, karena hukumnya harus diminati tentu konsep yang dimaksudkan itu adalah suatu ide yang abstrak tentu memungkinkan siswa untuk memberikan penjelasan serta mengelompokkannya (Ruseffendi, 1998).

Dalam mainset berpikirnya guru tentu bahwa pemahaman konsep matematika itu sendiri sangat dibutuhkan benar untuk bekal siswa dalam memperlajari matematika dalam kelas, karena sesungguhnya bahwa dengan menguasai konsep tersebut akan memperjelas siswa untuk mempelajari matematika. Walaupun pada hakikatnya selalu diketahui bahwa konsep apapun dalam matematika siswa selalu membahasakan konsep matematika itu rumit, susah dan sulit untuk dihafal maupun diingat karena selalu dekat dengan pola, hubungan dan penyelesainnya tidaklah muda.

Pada setiap pembelajaran terutama dalam matematika dikelas tentu yang menjadi acuan guru adalah ada pada penekanan penguasaan konsep supaya siswa memiliki bekal dasar yang utuh untuk mencapai kemampuan dasar yang lain seperti proses conjecturing matematis, komunikasi matematis serta penyelesaian masalah. Oleh karena itu, pemahaman konsep adalah kemampuan siswa yang berupa penguasaan sejumlah materi pelajaran, maksudnya adalah siswa tidak hanya mengingat beberapa konsep ada, tetapi mampu menjelaskan kembali dalam pola lain dan menerapkannya pada konsep yang sesuai struktur kognitif dari siswa itu sendiri (Sanjaya, 2009). 
Memaknai betapa pentingnya pemahaman konsep, tentu tidaklah hadir dengan sendirinya tanpa dibantu oleh suatu cara mengajar yaitu model pembelajaran yang dijadikan sebagai jalan untuk untuk mencapainya. Karena model dari pembelajaran itu sangat banyak dan bervariasi maka salah satu model pembelajaran tersebut adalah pembelajaran berbasis masalah, karena dengan model tersebut dianggap mampu mengarahkan siswa untuk menumbuh kembangkan minat terhadap konsep yang ada dalam matematika.

Model pembelajaran berbasis masalah akan mengarahkan siswa dalam memainkan perannya untuk memggali konsep yang dimiliki dan diterima melalui pembelajaran matematika, sebab pada model pembelajaran tersebut adalah mengutamakan permasalahan yang nyata. Schmit dan Moust (2000) dengan adanya PBL siswa membuat teori tentang dunia. PBL adalah suatu cara yang difokuskan pada aktivitas memberdayakan siswa untuk mengintegrasikan teori, menerapkan pengetahuan dan untuk menumbuhkembangkan keterampilan menemukan solusi sendiri (Savery, 2006; Arends, 2007).

Berbeda dengan temuan pada saat observasi disekolah menunjukkan bahwa guru sangat terlena dalam memainkan perannya dalam mengimplementasikan cara mengajarnya yang begitu sederhana dan instan. Guru lebih sering menyajikan pembelajaran dengan menjelaskan materi secara langsung sehingga penyampaian informasi hanya berlangsung satu arah (Fitrah, 2015).

Hal ini didukung dari jawaban guru matematika ketika peneliti melakukan wawancara bahwa implementasi dari PBL sangat jarang dilakukan tetapi guru hanya memanfaatkan masalah yang dekat dengan kehidupan siswa. Alasan ini diperkuat ketika pengamatan langsung dari aktivitas guru dalam kelas bahwa pembalajaran yang dimaksudkan itu banyak ribetnya, contohnya saja misalkan pada pembelajaran berbasis masalah guru dituntut untuk benar-benar kreatif mendesain suasana belajar sesuai dengan langkah-langkah yang ada karena setiap pembelajaran memiliki langkah-langkah masingmasing, setiap pertemuan harus menyusun LKS yang berbasis masalah, dan intrumen penilaian yang konkrit. Akhirnya lebih baik guru menggunakan yang ada seperti buku pegangan siswa karena sudah komplit.

Disisi lain selain bahwa cara mengajar guru lebih kepada orientasi menghabiskan materi, sedangkan pemahaman dan penguasaan konsep hanya berlalu tanpa ada perhatian yang khusus dari guru. Bermula pada metode yang digunakan oleh guru, tentu sesungguhnya siswa hanya mencatat, mendengarkan dan menjawab soal yang diberikan 
diatas kertas dan di papan tulis. Padahal pemahaman konsep dalam matematika haruslah dimiliki sepenuhnya oleh siswa untuk menjadi bekal dalam menerima materi selanjutnya dan bisa dikatakan sebagai materi prasyarat. Senada dengan pemaparan Fitrah (2016) bahwa lemahnya kemampuan dasar siswa pada konsep karena kurang menguasai materi prasyarat.

Terlepas dari hasil observasi dan wawancara dengan guru, maka berdasarkan hasil observasi awal di sekolah dengan siswa menunjukkan bahwa suasana belajar di kelas membosankan karena memang guru belum memaksimalkan ide kreatif yang dimilikinya dalam membuat suasana yang beragam sehingga akan menimbulkan semangat belajar menurun. Guru matematika hanya menggunakan metode itu-itu saja. Hal ini dibuktikan bahwa dengan rendahnya pencapaian hasil belajar siswa. Ini menandakan bahwa siswa hanya mampu menyelesaikan masalah secara instan tanpa membutuhkan proses yang konkrit. Kemudian hal ini dianalisis berdasarkan hasil yang dicapai oleh siswa pada lembar kerja siswa dan hasil ulangan harian bahwa siswa sangat lemah pada konsep yang diterapkan oleh guru. Konsep tersebut dalam hal ini di gambarkan adalah langkah-langkah penyelesaiannya. Siswa tidak mampu mengeksplorasikan kemampuan berpikirnya dalam menemukan solusi yang tepat.

Berdasarkan pemaparan teori dan hasil observasi disekolah, maka salah satu solusinya adalah guru mengimplementasikan metode pembelajaran berbasis masalah atau dikenal dengan Problem Based Learning (PBL), karena PBL sudah terbukti memberikan efek positif terhadap pemahaman siswa dalam mempelajari matematika. Beberapa hasil penelitian yang menyatakan bahwa PBL memberikan efek positif terhadap kemajuan pengetahuan siswa pada matematika dalam menyelesaikan masalah matematika (Sastrawati, dkk., 2011; Yuniarti, 2014).

Pencapaian hasil dari beberapa penelitian tersebut tentu tidak pandu dengan adanya langkah-langkah pada pembelajaran berbasis masalah, karena tentu sesungguhnya langkahlangkah inilah yang akan mengarahkan guru atau peneliti memperoleh hasil yang maksimal. Langkah-langkah dalam pembelajaran berbasis masalah, antara lain seperti pada tabel dibawah ini.

Tabel.1. Langkah-langkah pembelajaran berbasis masalah

\begin{tabular}{ll}
\hline \multicolumn{1}{c}{ Langkah-langkah } & \multicolumn{1}{c}{ Aktivitas Sang Guru } \\
\hline Pertama: memberikan orientasi & $\begin{array}{l}\text { menyampaikan tujuan pembelajaran dan memberikan memotivasi kepada siswa untuk } \\
\text { terlibat dalam kegiatan mengatasi masalah. }\end{array}$ \\
\hline Kedua: mengorganisasi & $\begin{array}{l}\text { membantu siswa mendefinisikan dan mengorganisasikan tugas-tugas belajar yang } \\
\text { berhubungan dengan permasalahan yang ada }\end{array}$ \\
\hline Ketiga: membantu investigasi & mendorong siswa untuk mendapatkan informasi yang akurat, melaksanakan percobaan dan \\
\hline
\end{tabular}




\begin{tabular}{ll}
\hline $\begin{array}{l}\text { Keempat: mengembangkan dan } \\
\text { mempresentasikan }\end{array}$ & $\begin{array}{l}\text { atau penggalian masalah, serta mencari penjelasan dan solusi } \\
\text { dan model-model serta membantu siswa untuk menyampaikannya untuk orang lain }\end{array}$ \\
\hline Kelima: menganalisis dan mengevaluasi & $\begin{array}{l}\text { membantu siswa melakukan refleksi terhadap aktivitas investigasi yang dilakukan dan } \\
\text { proses-proses yang mereka terapkan }\end{array}$ \\
\hline (Rusman, 2010; Suprijono, 2012) &
\end{tabular}

Tentu untuk mencapai hasil yang maksimal, maka PBL tersbut sangat memaksimalkan peran guru dalam menyampaikan materi saat belajar atau lebih sederhananya adalah guru bukan semata-mata sebagai sumber utama yang menjelaskan materi didepan kelas. Untuk merespon hal demikian maka dalam PBL peran guru terlepas dari peran utamanya adalah sebagai berikut: 1) menekankan belajar kooperatif; 2) melaksanakan dan mengatur lingkungan belajar untuk mendorong keterlibatan siswa dalam masalah; 3) menyiapkan karangka berpikir siswa (Rusman, 2010; Akçay, 2009), dan 4) desain kerangka berpikir siswa terhadap masalah lebih difokuskan masalah yang ada dalam kehidupan nyata siswa itu sendiri (Fitrah, 2016).

Berdasarkan pemaparan masalah, maka disimpulkanlah beberapa rumusan masalah yang urgen dalam penelitian ini, antara lain sebagai berikut:

1. Bagaimana aktivitas guru dan siswa pada pembelajaran berbasis masalah yang dapat meningkatkan pemahaman konsep matematika materi segiempat?

2. Sejauh mana peningkatan pemahaman konsep matematika materi segiempat melalui model pembelajaran berbasis masalah?

3. Bagaimana respon siswa terhadap penerapan model pembelajaran berbasis masalah untuk meningkatkan pemahaman konsep matematika materi segiempat?

\section{METODE PENELITIAN}

Penelitian ini adalah penelitian tindakan kelas, secara umum terdapat empat tahapan penelitian tindakan kelas, antara lain: 1) perencanaan; 2) pelaksanaan; 3) pengamatan, dan 4) refleksi. Pelaksanaan penelitian ini di SMP Negeri 1 Dompu, Jln. Lele Sawete Bali $1 \mathrm{Kec}$. Dompu Kab. Dompu-NTB. Subjek dari penelitian adalah siswa kelas VIIA sebanyak 34 orang. Pendekatan penelitian adalah pendekatan penelitian kualitatif dan kuntitatif. Data kualitatif dalam penelitian ini berupa data hasil pengamatan terhadap aktivitas belajar siswa, guru, dan respon siswa sedangkan data kuantitatifnya adalah berupa presentase dan skor.

Data diperoleh melalui instrumen yaitu lembar tes, observasi, angket, dan kemudian dilengkapi dengan pedoman wawancara. Lembar tes dalam hal ini adalah soal uraian yang dibuat sebanyak empat soal, kemudian lembar observasinya sesuai dengan aktivitas siswa 
yang didesain berdasarkan langkah-langkah PBL. Sedangkan angket dalam penelitian ini berisikan beberapa pertanyaan yang sesuai dengan kondisi siswa itu sendiri guna mengukur respon siswa terhadap implementasi PBL. Sehingga dari data yang diperoleh menggunakan lembar tes dibantu dengan pedoman wawancara yang akan mengarahkan pembuktian jawaban dari siswa yang berhubungan dengan pemahaman konsep matematika. Berikut adalah salah satu contoh soal untuk mengukur kemampuan siswa dalam memahami konsep matematika, antara lain:

Seorang petani mempunyai sebidang tanah yang berukuran panjang $24 \mathrm{~m}$ dan lebar $15 \mathrm{~m}$.

Tanah tersebut akan dibuat sebuah kolam berbentuk belah ketupat dengan panjang diagonaldiagonalnya berturut-turut $9 m$ dan $12 m$, sedangkan sisanya akan ditanami pohon pisang.

Berapakah luas tanah yang ditanami pohon pisang?

Sumber data penelitian berasal dari: 1) data hasil tes pemahaman konsep matematika, diperolah dari dari lembar jawaban tes, serta lembar kerja siswa; 2) data hasil observasi yang diperoleh dari lembar observasi siswa dan guru, dan 3) data dari hasil angket respon siswa terhadap model pembelajaran yang dimaksudkan. Kemduain dari data yang diperoleh tersebut tentu akan di tafsirkan berupa rata-rata, dan persentase dan lalu dikaloborasikan dengan jawaban siswa dan guru yang didapatkan dari pedoman wawancara.

\section{HASIL DAN PEMBAHASAN}

Hasil dan pembahasan dari penelitian ini tentu beracukan terhadap rumusan masalah yang didesain berdasarkan langkah-langkah desain pembelajaran yang dipilih yaitu penelitian tindakan kelas. Penelitian tindakan kelas lebih kepada penekanannya pada proses yang dilakukan dalam menemukan jawaban atas masalah-masalah yang di paparkan pada sebelumnya.

Sebagai gambaran umum peneliti menggambarkan proses belajar mengajar dikelas dengan satu kali pertemuan. Walaupun pada penelitian ini digunakan selama dua siklus dengan jumlah pertemuan sebanyak delapan kali pertemuan, sehingga disimpulkanlah hasil penelitian. Penggambarannya adalah berdasarkan langkah-langkah penelitian tindakan kelas, yaitu perencaanaan, pelaksanaan tindakan, pengamatan atau observasi dan refleksi.

Tindakan pada siklus pertama dan kedua terdiri dari perencanaan, pelaksanaan, observasi, dan refleksi. Adapun tujuan pembelajaran yang diharapkan pada tindakan siklus pertama adalah agar siswa dapat: 1) menemukan konsep dan sifat-sifat trapesium dari situasi nyata kehidupan, dan 2) menemukan konsep dan sifat-sifat serta rumus luas dan 
keliling jajargenjang. Sedangkan pada tindakan siklus kedua adalah agar siswa dapat: 1) menemukan konsep dan sifat-sifat belahketupat; 2) menemukan konsep layang-layang dari pengamatan situasi nyata dalam kehidupan.

\section{Perencanaan}

Untuk siklus pertama dan kedua pada tahap perencanaan ini kegiatan yang dilakukan sama, karena terfokus pada instrumen yang digunakan dalam mendukung keberhasilan yang akan dicapai selama penelitian berlangsung dengan materi utamanya adalah segiempat, antara adalah: 1) menyiapkan RPP; 2) menyiapkan alat peraga; 3) menyiapkan LKS; 4) menyiapkan lembar pengamatan dan catatan lapangan, 5) menyediakan lembar tes pemahaman konsep matematika, dan 5) menyiapkan kamera digital.

Setelah peneliti merancang semua kebutuhan dalam pembelajaran, selanjutnya pada tahap ini peneliti meminta kepada dua orang validator untuk melakukan validasi semua perangkat pembelajaran dalam penelitian yang akan digunakan. Pemilihan dua orang tersebut dengan pertimbangan karena secara teori memahami matematika.

\section{Pelaksanaan}

Pelaksanaan kegiatan pembelajaran pada siklus pertama uraikan dalam dua kali pertemuan dengan satu kali untuk evaluasi dan satu kali untuk wawancara skala kecil sehingga pada siklus pertama ini jumlah pertemuannya adalah empat kali pertemuan, sedangkan untuk siklus kedua sama dengan siklus pertama sebanyak 4 kali pertemuan pula.

Dibawah ini peneliti memaparkan proses penelitian sebagai contoh hanya satu kali pertemuan, antara lain: Pertemuan pertama pada materi trapesium, pelaksanaan tindakan dimulai guru dengan mengabsen siswa. Siswa yang hadir pada pertemuan pertama 32 orang dan yang tidak hadir dua orang siswa. Pembelajaran diawali dengan peneliti menyampaikan langkah-langkah pembelajaran yang akan dilakukan yaitu PBL yang akan memainkan peran belajar pada suasana kelompok. Dan pembelajaran dibagi dalam tiga tahap sesuai dengan perangkat pembelajaran yang didesain yaitu tahap awal, tahap inti, dan tahap akhir.

Pada tahap awal, peneliti menyampaikan pentingnya mempelajari trapesium di dalam kehidupan yaitu banyak bentuk trapesium ditemui di kehidupan sekitar siswa itu sendiri seperti "pangaha bunga (makanan khas Bima-Dompu)", penghapus, dan lain-lain. 
Selanjutnya menyampaikan tujuan yang ingin dicapai di dalam pembelajaran trapesium dengan bantuan alat peraga dan LKS 1 yang telah disediakan. Pada tahap awal ini pula didiskusikan tentang luas persegi panjang yang ditarik menjadi bentuk trapesium siku-siku. Kemudian tahap awal diakhiri dengan pengecekan pengetahuan prasyarat siswa sebagai prasyarat untuk tahap berikutnya dan kemudian siswa diminta menempati kelompok sesuai daftar nama-nama anggota kelompok yang telah dibagikan sebelumnya.

Selanjutnya kegiatan inti terdiri dari pelaksanaan diskusi kelompok dan presentasi hasil diskusi kelompok. Sebelum melaksanakan diskusi, guru membagikan pada tiap kelompok LKS 1 yang berbeda. Kegiatan diskusi ini berlangsung 45 menit, lima menit lebih lama dari waktu yang direncanakan.

Selama diskusi berlangsung, guru berkeliling untuk memonitor aktivitas siswa. Dari hasil pengamatan guru tampak setiap kelompok aktif dalam melakukan investigasi sifatsifat dari trapesium, hampir setiap anggota dalam kelompok aktif ambil bagian. Namun masih ada kelompok yang didominasi oleh dua atau tiga orang saja. Untuk kelompok yang seperti ini, dilakukan pendekatan dengan cara memotivasi siswa yang tidak aktif agar ikut ambil bagian dalam menyelesaikan tugas dan meminta siswa yang mendominasi kelompoknya agar mau bekerjasama. Beberapa anggota kelompok lain sibuk memperhatikan LKS masing-masing.

Dari hasil pengamatan peneliti hampir semua kelompok tidak mengalami kesulitan dalam menyelesaikan masalah yang diberikan. Namun saat menyelesaikan masalah, ada kelompok yang masih terlihat bingung. Kemudian peneliti mengingatkan tentang trapesium. Akhirnya anggota kelompok memahami apa yang menjadi kesulitan mereka.

Kegiatan selanjutnya adalah kegiatan presentasi hasil diskusi. Guru memberikan kesempatan kepada salah satu kelompok untuk mempresentasikan hasil diskusinya. Pada saat presentasi kelompok suasana kelas agak sedikit ribut, sehingga peneliti perlu menenangkan. Suasana diskusi kelas belum berjalan secara oprtimal, sehingga peneliti masih perlu memotivasi siswa untuk memberikan tanggapan terhadap hasil diskusi kelompok penyaji.

Berdasarkan kegiatan diskusi kelompok dan diskusi kelas yang telah dilakukan siswa, kemudian guru meminta siswa menyimpulkan tentang trapesium secara umum. Secara serempak siswa menyimpulkan bahwa luas dan keliling trapesium. Kemudian guru meminta siswa untuk mengatur tempat duduk masing-masing agar ditata kembali seperti 
semula. Pembelajaran harus segera diakhiri karena tanda bel pergantian jam telah berbunyi.

\section{Pengamatan}

Hasil observasi dua observer terhadap pelaksanaan pembelajaran menunjukkan bahwa pembelajaran telah berlangsung cukup baik karena tahapan-tahapan yang direncanakan dalam RPP dapat terlaksana walaupun ada sebagian yang belum dilaksanakan oleh guru. Berdasarkan pengamatan peneliti dan dua orang observer selama proses pembelajaran berlangsung terlihat bahwa siswa dapat merespon pembelajaran dengan baik. Sosialisasi siswa dalam diskusi sudah cukup baik. Mereka cukup antusias dalam mengikuti pembelajaran yang dilaksanakan dan cukup aktif berdiskusi. Sebagian besar siswa sudah berani untuk mengungkapkan ide-idenya pada temannya dalam satu kelompok, demikian juga saat diskusi kelas pada pertemuan pertama hingga pertemuan keempat.

\section{Refleksi}

Refleksi dilakukan untuk menentukan apakah tindakan siklus pertama telah berhasil atau tidak. Kriteria keberhasilan pada tindakan siklus pertama ini jika ada minimal satu kelompok yang berhasil menemukan dan memahami konsep dari trapesium dan jajargenjang serta kriteria penilaian proses pembelajaran. Sehingga pada akhirnya siklus pertama harus dilanjutkan ke tindakan siklus kedua dengan materi yang berbeda dari tindakan siklus pertama yaitu Belah Ketupat, Layang-layang dan pada akhirnya refleksi dilakukan untuk menentukan apakah tindakan siklus kedua telah berhasil sesuai dengan kriteria keberhasilan.

Berdasarkan hasil pengamatan yang dilakukan selama dua siklus yang dilaksanakan maka diperolehlah aktivitas guru dan siswa pada pelaksanaan pembelajaran berbasis masalah, antara lain:

1. Aktivitas Guru Dan Siswa Pada Pembelajaran Berbasis Masalah Yang Dapat Meningkatkan Pemahaman Konsep Matematika Materi Segiempat

Tabel. 2. Hasil observasi aktivitas Guru Siklus Pertama dan Kedua

\begin{tabular}{cccccc}
\hline & \multicolumn{2}{c}{ Siklus Pertama } & \multicolumn{3}{c}{ Siklus Kedua } \\
\cline { 2 - 5 } & Observer Pertama & Observer Kedua & Observer Pertama & Observer Kedua \\
\hline Jumlah Indikator & & & 16 & & 77 \\
\hline Jumlah skor & 73 & 75 & & 79 & $96,25 \%$ \\
\hline Skor Maksimal & $91,25 \%$ & $93,75 \%$ & & $98,75 \%$ & 90 \\
\hline$\%$ & & &
\end{tabular}


Berdasarkan data observasi pada Tabel 2, dari kedua observer diperoleh jumlah skor yang diperoleh dari observer pertama adalah 73 dari skor maksimal 80, persentase nilai rata-ratanya adalah $91,25 \%$ berada pada kategori sangat baik. Sedangkan jumlah skor yang diperoleh dari observer kedua adalah 75 dari skor maksimal 80, persentase nilai rataratanya adalah 93,75\% sehingga berada pada kategori sangat baik untuk siklus pertama. Sedangkan pada siklus kedua berdasarkan data observasi dari kedua observer diperoleh jumlah skor yang diperoleh dari pengamat pertama adalah 79 dari skor maksimal 80, persentase nilai rata-ratanya adalah $98,75 \%$ berada pada kategori sangat baik. Sedangkan jumlah skor yang diperoleh dari pengamat kedua adalah 77 dari skor maksimal 80, persentase nilai rata-ratanya adalah $96,25 \%$ sehingga berada pada kategori sangat baik.

Pada tabel.1 diatas menunjukkan bahwa aktivitas guru pada pelaksanaan model pembelajaran berbasis masalah mengalami peningkatan dari siklus pertama dan kedua, hal ini bukti dari penilaian yang dilakukan oleh tim observer sebanyak dua orang. Pada aspek penilaian aktivitas guru terdapat 16 indikator yang disesuaikan dengan langkah-langkah pembelajaran berbasis masalah yang dirujuk pada lima fase utama. Pada langkah-langkah pembelajaran berbasis masalah guru melakukan inovasi menyusun masalah untuk diselesaikan oleh siswa dalam kelompok yang berjumlah kecil. Pembelajaran berbasis masalah ini memberikan masalah di awal pembelajaran, sehingga peran guru dalam membimbing harus optimal (Setiyani., dkk, 2016). Rusmono (2012) yang mengemukakan salah satu karakteristik guru dalam pembelajaran berbasis masalah adalah kemampuan membangkitkan lingkungan yang santai dan tidak mengancam sambil terus bertindak mengembangkan diskusi dan berpikir kritis. Lebih lanjut Fitrah (2015) menjelaskan kemampuan guru sangatlah penting dan menjadi alasan utama untuk menjadikan proses belajar menjadi kondusif, aktif, dan komperehensif dalam mengelola kelas.

Penelitian ini juga terlepas dari hasil yang meningkat disetiap siklusnya menunjukkan bahwa aktivitas guru sangatlah menentukan keberhasilan siswa dalam memahami matematika, dan terbukti bahwa pada PBL memberikan ruang gerak guru untuk memainkan perannya dalam mendesain suasana belajar siswa dan aktivitas guru sangat aktif. Senada dengan hasil penelitian dari Vivin Nurul Agustin (2013) bahwa pembelajaran berbasis masalah dapat meningkatkan performansi guru dalam pembelajaran matematika (Evi Nurul Khuswatun, 2013). Peningkatan performansi guru dalam menerapkan model pembelajaran berbasis masalah pada pembelajaran matematika dinilai dari kemampuan 
guru dalam pelaksanaan pembelajaran berdasarkan penyusunan RPP pembelajaran berbasis masalah.

Tabel. 3. Hasil observasi aktivitas Siswa Siklus Pertama dan Kedua

\begin{tabular}{cccccc}
\hline & \multicolumn{2}{c}{ Siklus Pertama } & \multicolumn{2}{c}{ Siklus Kedua } \\
\hline & Observer Pertama & Observer Kedua & Observer Pertama & Observer Kedua \\
\hline Jumlah Indikator & 73 & & 13 & & 63 \\
\hline Jumlah skor & & 75 & & 64 & \\
\hline Skor Maksimal & $92,31 \%$ & $93,85 \%$ & & $98,46 \%$ & $96,92 \%$ \\
\hline$\%$ & & & 65 & \\
\hline
\end{tabular}

Berdasarkan data observasi pada Tabel 3, dari kedua observer di atas diperoleh jumlah skor dari observer pertama adalah 60 dari skor maksimal 65, persentase nilai rataratanya adalah $92,31 \%$ berada pada kategori sangat baik. Sedangkan jumlah skor yang diperoleh dari observer kedua adalah 61 dari skor maksimal 65, persentase nilai rataratanya adalah 93,85\% sehingga berada pada kategori sangat baik untuk tindakan siklus pertama. Sedangkan pada tindakan siklus kedua berdasarkan data observasi dari kedua observer di atas diperoleh jumlah skor dari pengamat pertama adalah 64 dari skor maksimal 65, persentase nilai rata-ratanya adalah $98,46 \%$ berada pada kategori sangat baik. Sedangkan jumlah skor yang diperoleh dari pengamat kedua adalah 63, persentase nilai rata-ratanya adalah $96,92 \%$ sehingga berada pada kategori sangat baik.

Berdasarkan tabel. 2 menunjukkan bahwa aktivitas siswa pada pembelajaran berbasis masalah sangatlah mendukung keberhasilan pencapaian siswa dalam proses belajar siswa pada matematika materi segiempat. Sanada dengan hasil penelitian Evi Nuru Khuswatun (2013) bahwa pembelajaran berbasis masalah dapat meningkatkan aktivitas belajar siswa. Hal ini terlihat pada aktivitas siswa dalam kelompok belajar yang berjumlah empat dan lima orang. Pada kelompok tersebut siswa sangat termotivasi untuk menemukan hal-hal baru serta saling memaparkan ide-ide penyelesaian suatu masalah pada segiempat. Senada dengan pendapat Delisle (1997) yang memandang bahwa kedudukan siswa dalam pembelajaran berbasis masalah bukan sebagai pengungkap kembali informasi melainkan untuk mendemonstrasikan pemahaman mereka. Salah satu kegiatan siswa dalam hal ini adalah dalam belajar kelompok siswa meluangkan ide untuk mencari solusi dari masalah yang ada, ini menggambarkan bahwa pemecahan masalah yang dilakukan oleh siswa dalam kelompok tersebut menumbuhkan siswa untuk mengasah kemampuan representasikan masalah matematika yang diberikan.

2. Pemahaman Konsep Matematika Siswa Kelas VIIA Pada Materi Segiempat Melalui Model Pembelajaran Berbasis Masalah 
Terlepas dari data aktivitas guru dan siswa diatas maka pada penelitian ini difokuskan pada pemahaman konsep matematika siswa kelas VIIA di SMP Negeri 1 Dompu pada materi segiempat. Data tentang pemahaman konsep matematika siswa tersebut dikumpulkan dan dianalisis berdasarkan hasil evaluasi pada setiap siklus. Karena pada penelitian ini pelaksanaan di dua siklus maka diperolehlah data seperti pemaparan pada tabel 4 di bawah ini.

Tabel. 4. Ringkasan Tes Pehamaman Konsep Siswa Siklus Pertama dan siklus Kedua

\begin{tabular}{ccccccc}
\hline Siklus & \multicolumn{5}{c}{ Pemahaman Konsep } \\
\cline { 2 - 7 } & $\begin{array}{c}\text { Jumlah } \\
\text { Siswa }\end{array}$ & $\begin{array}{c}\text { Siswa yang } \\
\text { Tuntas }\end{array}$ & $\begin{array}{c}\text { Siswa yang } \\
\text { Tidak Tuntas }\end{array}$ & $\begin{array}{c}\text { Rata-rata } \\
\text { Nilai }\end{array}$ & $\begin{array}{c}\text { Presentase } \\
\text { Ketuntasan Belajar }\end{array}$ & Simpanan Baku \\
& 34 & 27 & 7 & 77,35 & $79,41 \%$ & 15,91 \\
\hline I & & 30 & 4 & 84,26 & $88,24 \%$ & 12,90 \\
\hline
\end{tabular}

Berdasarkan hasil analisis dari tes kemampuan pemahaman konsep matematika siswa kelas VIIA materi segiempat, menunjukkan bahwa siswa tuntas pada siklus ke kedua. Pada siklus pertama bahwa presentase ketuntasan belajar materi segiempat yaitu 79, $41 \%$ dengan rata-rata nilainya adalah 77,35. Hal ini diperoleh dari siswa sebanyak 34 orang dan siswa yang tuntas sebanyak 27 dan yang tidak tuntas sebanyak tujuh orang. Sedangkan pada siklus kedua pemahaman konsep matematika siswa meningkat secara signifikan, hal ini terbukti presentasenya adalah $88,24 \%$ dengan rata-rata nilainya adalah 84,26 . Hal ini dibuktikan pada jumlah siswa 34 orang yang tuntas yaitu 30 dan siswa yang tidak tuntas sebanyak empat orang.

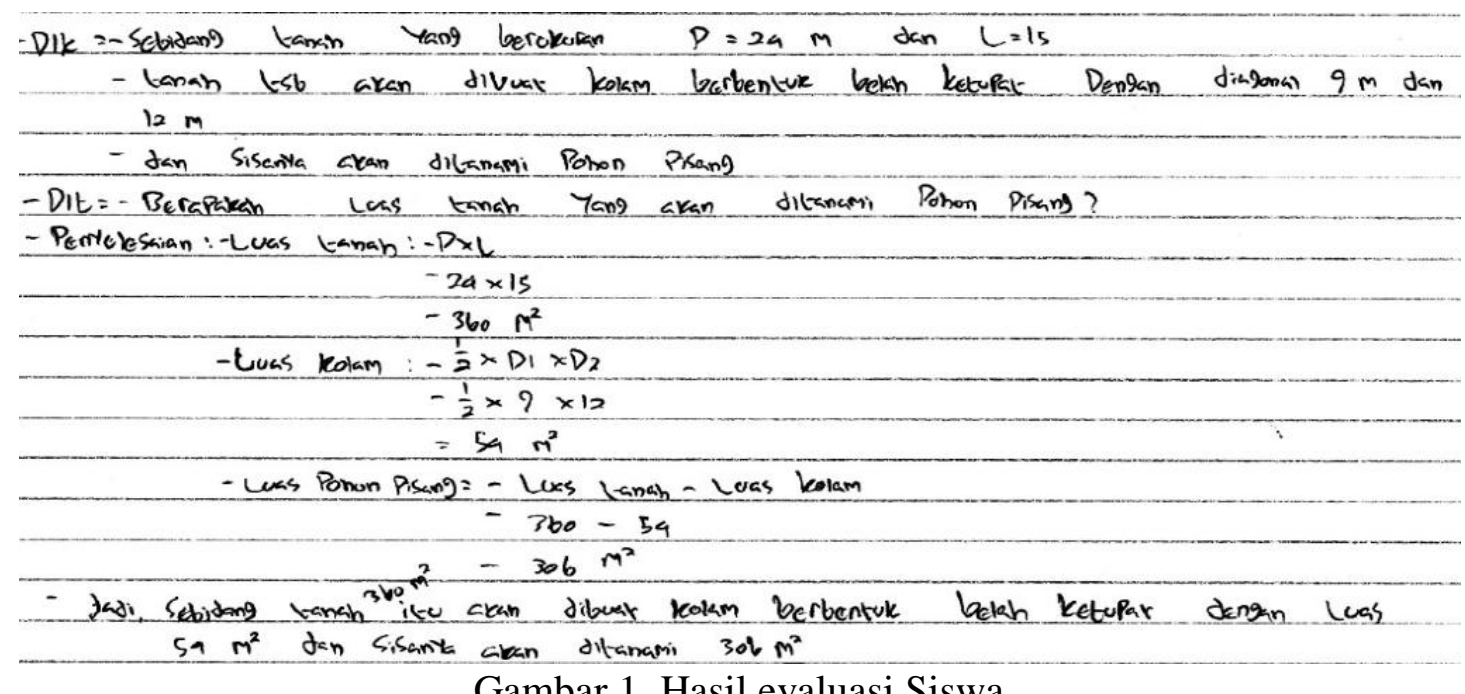

Gambar 1. Hasil evaluasi Siswa

Hasil tersebut menggambarkan bahwa pembelajaran berbasis masalah sangat membantu atas perkembangan pemahaman konsep matematika pada materi segiempat. Pembuktiannya adalah siswa memiliki kesanggupan dalam mengetahui dan menjelaskan kembali konsep yang telah dipelajari sebelumnya serta mampu memaparkan objek 
matematika terutama yang difokuskan adalah objek dari materi segiempat. Senada dengan hasil penelitian dari Sahin (2010) menyebutkan bahwa PBL berpengaruh positif terhadap pemahaman konsep (Evi Nurul Khuswatun, 2013; Tomi Utomo., dkk, 2014). Hal ini tertera dari hasil analisis bahwa peningkatan pemahaman konsep dari siklus pertama ke siklus kedua serta ketercapaian indikator keberhasilan. Perubahan perkembangan proses penyelesaian masalah siswa dalam mengidentifikasi pemahaman konsep terlihat bahwa siswa telah mampu menyelesaikan masalah yang diberikan secara konkrit.

Jika dipahami dalam penelitian ini adalah permasalahan awal digambarkan adalah siswa masih secara instan menyelesaikan masalah, sehingga dengan adanya impelementasi pembelajaran berbasis masalah mampu mengarahkan siswa untuk menyelesaikan masalah dengan langkah step by step, seperti yang tertera pada gambar 1. Hal demikian bisa disimpulkan bahwa salah satunya adalah siswa mampu menyajikan konsep dalam bentuk representasi matematisnya. Senada dengan hasil penelitian dari Setiyani., dkk (2016) yang memaparkan pembelajaran berbasis masalah memberikan pengaruh yang sangat jelas terhadap kemampuan representasi matematis (Mahardiyanti, 2014).

Peningkatan pemahaman siswa terhadap konsep matematika memiliki makna yang sangat berpengaruh pada perkembangan belajar siswa kedepan. Pembelajaran berbasis masalah memberikan pengalaman belajar yang sangat berarti bagi siswa untuk dijadikan sebagai dasar proses belajar melalui aktivitas investigasi secara kelompok dalam menemukan solusi terhadap permasalahan matematika yang diajukan guru oleh guru saat pembelajaran berlangsung. Senada dengan uraian Aunurrahman (2009) perubahan perilaku pada diri individu terjadi dengan adanya interaksi antara siswa dengan siswa serta siswa dengan lingkungannya. Saat siswa menemukan solusi terhadap masalah, saat itulah sesungguhnya siswa menyiapkan mental untuk memahami konsep yang diajarkan. Senada dengan ungkapan Zohar (1994) yang mengemukakan bahwa proses belajar akan terjadi karena adanya kesiapan siswa dan pemahaman konsep tidak akan berkembang tanpa adanya usaha yang sengaja ditanamkan (Slameto, 2003).

Keberhasilan pencapaian pada penelitian ini dilihat juga perkembangan siswa dalam memecahkan masalah dalam kehidupan sehari-hari. Hasil penelitian menunjukkan bahwa model pembelajaran berbasis masalah efektif ditinjau dari kemampuan pemecahan masalah (Angkotasan, 2014; Sari, 2014). Uden \& Beaumont (2005) menyebutkan bahwa dalam pembelajaran PBL siswa dapat mempertahankan atau menyimpan pengetahuan lebih lama dibandingkan dengan kelas tradisional. 
Secara umum peneliti ingin menjelaskan bahwa pembelajaran berbasis masalah sangat membantu siswa dalam meningkatkan kemampuan pemahaman konsep matematika, sebab jika dianalisis lebih tajam dikarenakan pada aktivitas guru yang membantu siswa melakukan investigasi, menganalisis dan mengevaluasi proses penyelesaian masalah ketika pembelajaran didesain secara kelompok kaloboratif. Hal ini senada dengan karakteristik PBL yaitu menciptakan lingkungan belajar agar siswa mampu untuk menuangkan kemampuan berpikir kritis dan masalah menjadi titik awal pembelajaran (Sahin \& Yorek, 2009; Chen, 2013; Abidin, 2014).

Terlepas dari data diatas bahwa pembelajaran berbasis masalah sangatlah penting untuk dimiliki siswa, karena dengan adanya pemahaman konsep matematika yang kuat dalam diri siswa tentu selanjutnya siswa dalam belajar sangatlah mudah dan dikuasi oleh siswa. NCTM (2000) menjelaskan bahwa pemahaman konsep matematika merupakan aspek yang sangat penting dalam prinsip pembelajaran matematika, karena pemahaman konsep merupakan prasyarat seseorang untuk memiliki kemampuan pemecahan masalah. Sebab, ketika seseorang belajar matematika memahami konsep-konsep, maka saat itulah orang tersebut mulai merintis kemampuan-kemampuan berpikir matematis. Hal tersebut sesuai dengan pendapat Utari Sumarmo (2010) yang menyatakan pemahaman konsep penting dimiliki siswa, karena diperlukan untuk menyelesaikan masalah matematika, masalah dalam disiplin ilmu lain, dan masalah dalam kehidupan sehari-hari, yang merupakan visi pengembangan pembelajaran matematika untuk memenuhi kebutuhan masa kini.

3. Respon Siswa Pada Model Pembelajaran Berbasis Masalah Untuk Meningkatkan Pemahaman Konsep Matematika Materi Segiempat

Pada penelitian ini, khususnya menganalisis aktivitas guru dan siswa serta pemahaman konsep matematika siswa pada materi segiempat. Untuk mengetahui minimal hubungan model pembelajaran dalam aktivitas guru dan siswa serta pemahaman konsep matematika, peneliti menggunakan angket respon siswa pada pembelajaran berbasis masalah dengan aspek antara lain: 1) mendorong siswa untuk menggali pemahaman konsep matematika; 2) cara belajar; 3) bekerja sama dalam kelompok, dan 4) penyelesaian masalah-masalah dunia nyata. Pada aspek tersebut memiliki 10 indikator yang mewakili pembelajaran berbasis masalah. 
Tabel. 5. Respon siswa pada Pembelajaran Berbasis Masalah

\begin{tabular}{lc}
\hline \multicolumn{1}{c}{ Aspek } & Presentase (\%) \\
\hline Mendorong siswa untuk menggali pemahaman konsep matematika & 29,46 \\
\hline Cara Belajar & 54,54 \\
\hline Bekerja sama dalam Kelompok & 27,89 \\
\hline Penyelesaian Masalah-Masalah Dunia Nyata & 22,38 \\
\hline
\end{tabular}

Tabel 5 menunjukkan pembelajaran berbasis masalah dengan adanya kelompok

kecil dengan anggota empat atau lima orang yang dirancang secara heterogen itu juga dianggap penting oleh semua siswa. Hasil penelitian menunjukkan bahwa siswa menyadari di dalam sebuah karya kelompok hasil dari diskusi, semua anggota diberi kesempatan untuk berbagi wawasan dan ide-ide dalam kelompok. Saat melakukan aktivitas, siswa menyadari bahwa kerjasama akan lebih efektif jika anggota kelompok memiliki lebih banyak pilihan yang tersedia sehingga dalam berdiskusi dapat membagi pengetahuan, pengalaman dan pandangan untuk kelompok.

Berangkat dari dua pokok utama dalam penelitian ini, tentu sesungguhnya kebermanfaatan dari pembelajaran berbasis masalah sangat diperlukan, maka data respon siswa terhadap pembelajaran berbasis masalah diperoleh dengan menggunakan angket respon siswa. Data respon siswa berfungsi untuk mengetahui pendapat siswa setelah penerapan pembelajaran berbasis masalah sesuai indikator yang ada pada lembar angket respon siswa.

Berdasarkan analisis respon siswa yang didapatkan di sekolah SMP Negeri 1 Dompu yang telah dikemukakan sebelumnya, menyatakan bahwa respon siswa terhadap PBL dapat melatih untuk meningkatkan kemampuan siswa dalam memahami konsep matematika seutuhnya yaitu mendapatkan respon positif. Hal demikian juga pada penelitian ini menunjukkan bahwa respon siswa dengan jumlah 34 orang pada aspek mendorong siswa untuk menemukan ide-ide baru dan memotivasi siswa dalam pembelajaran matematika.

Beberapa siswa memberikan alasan dengan aspek ini antara lain, yaitu:

Indikator menemukan ide-ide baru pada pembelajaran berbasis masalah dapat membuat siswa memahami dan menambah pengetahuan, mendapatkan proses menemukan rumus, serta memudahkan cara belajar siswa" sedangkan untuk Indikator memotivasi "dengan pembelajaran berbasis masalah siswa dapat percaya diri, semangat belajar dalam menyelesaikan masalah” 
Kemudian pada aspek cara belajar, hasil penelitian menunjukkan bahwa aktif kegiatan pembelajaran, memehami materi, latihan soal, dan mengeksplorasi diri. Hal ini didukung dengan alasan siswa yaitu

"tidak membuang waktu belajar, tugas selalu dikerjakan, memudahkan memahami masalah, dan bekerjasama dan leluasa berpendapat".

Respon siswa dalam menemukan pemahaman konsep matematika pada pembelajaran berbasis masalah, aktivitas guru dan siswa yaitu aspek penyelesaian masalah-masalah dunia yang nyata siswa masih lemah dalam menyelesaikan masalah jika dibandingkan aspek yang lainnya. Hasil penelitian Abdullah, et al. (2015) menunjukkan bahwa siswa dihadapkan dengan masalah ketika menghubungkan informasi dan ketika kegiatan dalam menemukan solusi atas masalah matematika. Selama proses dari PBL aktivitas belajar siswa dapat ditingkatkan dan kreativitasnya, sehingga respon siswa terhadap pembelajaran metematika menjadi positif (Nur Fauziah Siregar, 2015).

Perolehan hasil penelitian inipun memberikan gambaran bahwa masalah utama yang dikaitkan dalam proses pembelajaran adalah masalah yang benar-benar ada pada ruang linkup kehidupan siswa. Hal demikian sesuai dengan Chen (2013) yang memberikan penguat dalam hal ini yaitu pembelajaran berbasis masalah selalu identik dengan masalah yang dimanipulasi dari dunia nyata sebagai suatu konteks bagi pembelajar dalam belajar terutama keterampilan menyelesaikan masalah (Abidin, 2014).

Respon siswa terhadap pembelajaran berbasis masalah dalam penelitian ini sangat positif. Hal ini terlihat dari hasil angket siswa, dari hasil wawancara terhadap subyek wawancara secara umum menyatakan senang dan tertarik terhadap pembelajaran model pembelajaran berbasis masalah. Begitu pula pada catatan lapangan oleh guru dan pengamat menyimpulkan bahwa pembelajaran dengan model pembelajaran berbasis masalah dapat membuat siswa aktif dalam diskusi dan menyampaikan ide-idenya. Senada dengan hasil penelitian Sri Ismaya Nurbaiti., dkk (2016) bahwa pembelajaran berbasis masalah mampu mengubah pandangan dan anggapan siswa terhadap mata pelajaran matematika ke arah yang lebih baik.

Rasa senang siswa juga terlihat ketika melaksanakan penemuan dengan memanipulasi benda kongkret. Mereka terlihat seperti sedang bermain tetapi serius dalam bekerja, misalnya dalam kegiatan pengukuran, mamasukkan kubus-kubus satuan. Rasa senang siswa juga disebabkan oleh adanya kerja sama kelompok dalam menyelesaikan tugas. Dalam kelompok peran siswa dihargai oleh siswa lain. Penghargaan yang diberikan 
siswa lain ini menimbulkan perasaan senang pada diri siswa. Siswa menyatakan bahwa mereka senang belajar dengan metode penemuan berkelompok karena adanya kerja sama, saling menghormati, dan saling menghargai. Hal ini sesuai dengan pendapat Eggen \& Kauchak (2012) bahwa proses kerja sama dalam kelompok dapat menimbulkan motivasi instrinsik pada siswa, dan mendorong siswa untuk berpikir dalam proses pembelajaran (Awang \& Ramly, 2008).

\section{KESIMPULAN}

Berdasarkan dari hasil pembahasan yang telah dipaparkan diatas, maka disimpulkan bahwa PBL memberikan hasil yang sangat positif untuk peningkatan pemahaman konsep matematika terutama pada materi segiempat. Hal ini terbukti pada peningkatan setiap siklus yang dianalisis oleh peneliti pada hasil tes pemahaman konsepnya adalah pada siklus pertama 79,41\% dengan rata-rata nilainya adalah 77,35 dan pada siklus kedua meningkat secara signifikan, karena terlihat pada pencapaian presentasenya adalah $88,24 \%$ dengan rata-rata nilainya adalah 84,26 . Kemudian kegiatan guru sangat mendukung keberhasilan siswa dalam menggali konsep-konsep matematika itu sendiri, hal ini didukung pada kegiatan guru dan siswa berdasarkan dari retetan pada langkah-langkah pembelajaran berbasis masalah yaitu pada siklus pertama aktivitas guru dengan presentasenya 92,5\% meningkat disiklus kedua sebesar 97,5\%, sedangkan aktivitas siswa dengan presentasenya adalah 93,8\% dan meningkat pada siklus kedua sebesar 97,69\%. Sedangkan untuk respon siswa ketika pembelajaran berbasis masalah diterapkan pada materi segiempat pun mendapatkan respon positif karena sangat memotivasi siswa untuk terus melakukan penyelidikan terhadap masalah-masalah yang diberikan oleh guru sehingga sepenuhnya siswa mengetahui konsep matematika. Ini terbukti ketika siswa merasa senang dalam memainkan peran secara bersama pada kelompok serta memanipulasi hal-hal yang konkrit.

\section{REKOMENDASI}

Dari hasil penelitian ini, diharapkan kepada

1. Peneliti selanjutnya harus hati-hati dalam menggambarkan aktivitas siswa karena peneliti harus memahami benar setiap langkah-langkah dari pembelajaran yang diterapkan dan benar-benar harus disusun secara maksimal. 
2. Guru harus benar-benar kreatif dalam menyusun masalah matematika yang dijadikan sebagai sumber utama untuk menganalisis kemajuan pemahama konsep siswa terutama memanfaatkan masalah yang berkaitan langsung dengan kehidupan seharihari, sehingga memungkinkan siswa untuk terlibat secara maksimal dalam kegiatan pembelajaran matematika selain dari materi segiempat.

3. Terlepas dari keterampilan guru untuk mendesain masalah tersebut, gurupun harus mampu menghadirkan media yang mampu membantu keberlangsungan suasana belajar siswa dalam memahami dan menyelediki masalah dalam matematika.

4. Alokasi waktu perlu diatur semaksimal mungkin disetiap langkah-langkah pembelajaran berbasis masalah, karena dengan hal demikian guru akan mampu melihat kamajuan berpikir dan pemahaman konsep siswa.

\section{REFERENSI}

Abdullah, A.H., Abidin, N.L.Z., \& Ali, M. (2015). Analysis of students' errors in solving higher order thinking skills (HOTS) problems for the topic of fraction. Asian Social Science, 11(21), 133.

Abidin, Y. (2014). Desain Sistem Pembelajaran Dalam Konteks Kurikulum 2013. Bandung : PT Refika Aditama.

Agustin, V.N. (2013). Peningkatan Aktivitas dan Hasil Belajar Siswa melalui Model Problem Based Learning (PBL). Journal of Elementary Education, 2(1), 36-44.

Akçay, B. (2009). Problem-Based Learning in Science Education. Journal of Turkish Science Education, 6(1).

Angkotasan, N. (2014). Keefektifan Model Problem-Based Learning Ditinjau Dari Kemampuan Pemecahan Masalah Matematis. Delta-Pi: Jurnal Matematika dan Pendidikan Matematika. 3(1), 11-19.

Arends, R.I. (2007). Learning To Teach. New York: McGraw Hill Companies, Inc.

Aunurrahman. (2009). Belajar dan Pembelajaran. Bandung: Alfabeta.

Awang \& Ramly. (2008). Creative Thinking Skill Approach Through Problem-Based Learning: Pedagogy and Practice in the Engineering Classroom.International Journal of Human and Social Sciences, 3(1): 18-23.

Chen, H.W. (2013). Applying Problem-Based Learning Model and Creative Design to Conic-Sections Teaching. International Journal Of Education And Information Technologies, 3(7).

Delisle, R. (1997). How to Use Problem-Based Learning in the Classroom. Alexandria, VA: Association for Supervision and Curriculum Development.

Depdiknas. (2003). UU Nomor 20 tahun 2003 tentang Sisdiknas. Jakarta: Depdiknas.

Eggen, P., \& Kauchak, D. (2012). Strategies and Models for Teachers: Teaching Content and Thinking Skills, $6^{\text {th }}$ Edition. Boston: Pearson Education Inc.

Effendi, M. (2010). Prinsip Kurikulum Matematika Sekolah: Kajian Orientasi Pengembangan. Prosiding Seminar Nasional Matematika dan Pendidikan Matematika. ISBN 978-979-796-153-4. UMM Press.

Fitrah, M. (2016). Model Pembelajaran Matematika Sekolah; Kajian Perspektif Berdasarkan Teori dan Hasil Penelitian. Yogjakarta: Depublis. 
Fitrah, M. (2015). Kemampuan GuruMatematika dalam Mengelola Kelas Melalui Sumber Belajar untuk Meningkatka Aktivitas Siswa. Prosiding Seminar Nasional Matematika dan Pendidikan Matematika ISBN No. 978-979-028-728-0. Universitas Negeri Surabaya.

Khuswatun, E.N. (2013). Pendekatan Problem Based Learning (Pbl) Untuk Meningkatkan Pemahaman Konsep Siswa Pada Materi Bilangan Pecahan. Antologi PGSD Bumi Siliwangi, I(1).

Mahardiyanti, T. (2014). Penerapan Metode Pembelajaran Problem Based Learning (Pbl) Untuk Meningkatkan Kemampuan Representasi Matematis Siswa Kelas V Sdn Bader 01tahun Pelajaran 2014/2015. NUGROHO - Jurnal Ilmiah Pendididkan. 02(02), 142-149.

NCTM. (2000). Principles and standards for school mathematics. Reston, VA: NCTM.

Nurbaiti, S.I., dkk. (2016). Pengaruh Pendekatan Problem Based Learning Terhadap Kemampuan Komunikasi Matematis Dan Motivasi Belajar Siswa. Jurnal Pena Ilmiah. 1(1). 1001-1010.

Rusman. (2010). Model-Model Pembelajaran Mengembangkan Profesionalisme Guru. Jakarta: PT. Raja Grafindo Persada.

Ruseffendi. (1998). Statistika Dasar Untuk Penelitian Pendidikan. Bandung: IKIP Bandung Press

Rusmono. (2012). Strategi Pembelajaran dengan Problem Based Learning Itu Perlu untuk Meningkatkan Profesionalitas Guru. Bogor: Ghalia Indonesia.

Sahin, M. (2010). The Impact of Problem-Based Learning on Engineering Students' Beliefs about Physics and Conceptual Understanding of Energy and Momentum. European Journal of Engineering Education, 35(5), 1469-5898.

Sanjaya, W. (2009). Strategi Pembelajaran Berorientasi Standar Proses Pendidikan. Jakarta: Prenada.

Sari, S., dkk. (2014). Pengaruh Pendekatan Pembelajaran Berbasis Masalah Terhadap Kemampuan Pemecahan Masalah Matematika Siswa Kelas Viii Smp Negeri 1 Padang Tahun Pelajaran 2013/2014. Jurnal Pendidikan Matematika, Part 1, 3(2), 54-59.

Sastrawati., dkk. (2011). Problem-Based Learning, Strategi Metakognisi, dan Keterampilan Berpikir Tingkat Tinggi Siswa. Tekno-Pedagogi. 1(2).

Savery, J.R. (2006). Overview of Problem-based Learning: Definitions and Distinctions. Interdisciplinary Journal of Problem-Based Learning, 1(1).

Setiyani., dkk. (2016). Implementasi Pembelajaran Berbasis Masalah Terhadap Kemampuan Representasi Matematis Mahasiswa Tingkat 1 Pada Perkuliahan Statistika Dasar Di Fkip Unswagati Cirebon. Seminar Nasional Matematika dan Pendidikan Matematika (SNMPM) 2016 "Strategi Mengembangkan Kualitas Pembelajaran Matematika Berbasis Riset" Prodi Pendidikan Matematika FKIP Unswagati, Cirebon 6 Februari 2016. ISBN 978-602-71252-1-6.

Schmit, H.G., \& Moust, J.H.C. (2000). Factors Affecting Small-Group Learning: A Review Of The Research. In D. H. Evensen, \& C. E. Hmelo (Eds.), Problem-Based Learning: A Research Perspective On Learning Interactions.

Siregar, N.F. (2015). Penerapan Pembelajaran Berbasis Masalah Dalam Upaya Meningkatkan Kemampuan Pemecahan Masalah Matematika Siswa. Logaritma, III(02), 116-128.

Slameto. (2003). Belajar dan Faktor-Faktor yang Mempengaruhinya. Jakarta: PT. Rineka Cipta. 
Sumarmo, U. (2010). Berpikir dan Disposisi Matematik: Apa, Mengapa, dan Bagaimana Dikembangkan pada Peserta Didik. Artikel pada FPMIPA UPI Bandung.

Suprijono, A. (2012). Cooperatve Learning, Teori dan Aplikasi PAIKEM. Yogyakarta: Pustaka Pelajar.

Uden, L. \& C. Beaumont. (2005). Technology and Problem Based Learning. Hershey dan London: Infosci.

Utomo, T., dkk. (2014). The Effect of Problem-Based Learning Model to The Understanding of Concepts and Students Ability Think Creatively (at Odd Semester of VIII Grade Students of SMPN 1 Sumbermalang Situbondo in Academic Year 2012/2013. Jurnal Edukasi Unej, I(1), 5-9.

Yuniarti. T., dkk. (2014). Pengembangan Perangkat Pembelajaran Berbasis Masalah (Problem Based Learning) Dengan Pendekatan Ilmiah (Scientific Approach) Pada Materi Segitiga Kelas Vii SMP Se-Kabupaten Karanganyar Tahun Pelajaran 2013/2014. Jurnal Elektronik Pembelajaran Matematika, 2(9).

Zohar, A., (1994). The effect of Biology Critical Thinking Project in the Development of Critical Thinking. Journal of Research in Science Teaching, 31(2), 163-196. 